\title{
Cataract Surgical Planning Using Online Software vs Traditional Methods: A Time/Motion and Quality of Care Study [Corrigendum]
}

Gujral T, Hovanesian J. Clin Ophthalmol. 2021; The authors apologize for this error. 15:3197-3203.

The authors have advised that the funding statement on page 3203 is incorrect. The text "Alcon" should read "Carl Zeiss Meditec".

\section{Publish your work in this journal}

Clinical Ophthalmology is an international, peer-reviewed journal covering all subspecialties within ophthalmology. Key topics include: Optometry; Visual science; Pharmacology and drug therapy in eye diseases; Basic Sciences; Primary and Secondary eye care; Patient Safety and Quality of Care Improvements. This journal is indexed on PubMed
Central and CAS, and is the official journal of The Society of Clinical Ophthalmology (SCO). The manuscript management system is completely online and includes a very quick and fair peer-review system, which is all easy to use. Visit http://www.dovepress.com/ testimonials.php to read real quotes from published authors. 